\title{
DNA-barcoding contradicts morphology in quill mite species Torotrogla merulae and T. rubeculi (Prostigmata: Syringophilidae)
}

\author{
Eliza Glowska, Anna Dragun-Damian and Jacek Dabert
}

Department of Animal Morphology, Faculty of Biology, A. Mickiewicz University, Umultowska 89, 61-614 Poznań, Poland

\begin{abstract}
Torotrogla merulae Skoracki, Dabert et Ehrnsberger, 2000 and T. rubeculi Skoracki, 2004 have been considered as distinct steno- and monoxenous quill mite species (Acari: Prostigmata: Syringophilidae) parasitizing the thrushes of the genus Turdus Linnaeus and the European robin Erithacus rubecula (Linnaeus), respectively. Morphological and molecular studies on the taxonomical status of these two species provided contradictory results. Well defined differences in morphology were not supported by substantial genetic distance in nucleotide sequences of the DNA barcode (mitochondrial cytochrome c oxidase subunit I, COI, and D2 domain of the nuclear 28S rRNA gene), by the topology of the phylogenetic trees (neighbor-joining, maximum parsimony, maximum likelihood) and the network analyses of the COI haplotype genealogy (median-joining, statistical parsimony) that reveal rubeculi populations nested within merulae haplotypes. Since detected differences between T. merulae and T. rubeculi populations (1.6-2.4\% for $\mathrm{COI}$ and $0.1 \%$ for D2) are comparable to the intraspecific level observed in majority of currently recognized European Torotrogla species and are much lower than the interspecific distances observed in the genus, we postulate their conspecificity. Because main morphological distinctions concern the structures used for feeding, we hypothesize that they are the result of phenotypic plasticity evoked by specific and different environmental conditions prevailing on the host bodies (thickness of the feather quill wall).
\end{abstract}

Keywords: Acari, Torotrogla, COI, D2 28S rDNA, systematics, phenotypic plasticity

Biodiversity of mites (Acari) is currently the field of extensive studies all over the world. Each year many papers with descriptions of new taxa, based largely on external morphology, are published. Since the DNA barcoding system, using predominantly the nucleotide sequence of cytochrome oxidase subunit I (COI), has been proposed as an effective method for distinguishing the animal species (Hebert et al. 2003), some taxonomists begun to apply this approach in their investigations. Numerous studies show that the COI sequences of even closely related species differ by $c a$. ten fold the intraspecific variability and interspecific distance usually equals to or is higher than $3 \%$ ( $\mathrm{D} \geq 0.03$ - Sbordoni 2010), making it possible to identify most metazoan species with high confidence. Recently the D1-D2 region of the nuclear 28S rRNA gene has been proposed as a reliable barcode marker complementing analyses based on mitochondrial COI (Sonnenberg et al. 2007, Martin et al. 2010, Skoracka and Dabert 2010).

It is necessary to mention that the barcoding revolution and concept of DNA taxonomy have been widely debated in the past decade and besides the enthusiastic voices which saw in it a tool of unequivocal judge in taxonomic indecisions, it also provoked voices of opponents, who pointed out some deficiencies and limitations in the methods employed by Hebert et al. (2003).
They concerned mainly abandoning both morphological data and other crucial species descriptors in favour of a narrow molecular identification system and disregarding the nature of speciation events, different roles of genetic system, natural selection and evolutionary time (Sperling 2003, Tautz et al. 2003, Will and Rubinoff 2004, Sbordoni 2010). However, there is a general agreement that molecular data play indisputable role in the analysis of biodiversity and that sequence of the mitochondrial COI gene associated with nuclear DNA sequences are the markers most commonly and successfully used in phylogenetic, phylogeographic and population studies.

DNA barcoding is particularly valuable approach in cases, where classical identifying based on morphological features is misleading or very difficult. It concerns especially the species, which despite well expressed genetic separation are morphologically indistinguishable or the differences between them are very obscure. In these cases may increase considerably the overall taxonomic diversity (Hebert et al. 2004, Johnson et al. 2008, Lumley and Sperling 2010).

The opposite side of DNA barcoding, much less popularized, is the detecting of 'false' morphospecies and thus decreasing the described number of species (e.g. Otsuka et al. 1999, van Niekerk et al. 2004, Otranto et al. 2005,

Address for correspondence: E. Glowska, Department of Animal Morphology, Faculty of Biology, A. Mickiewicz University, Umultowska 89, 61-614 Poznan, Poland. Phone: +48 61829 5685; Fax: +48 61829 5687; E-mail: glowska@amu.edu.pl 
Pegler et al. 2005, Harper et al. 2009, Vrijenhoek 2009, Wilson et al. 2010).

Molecular diagnostics may be also used with success in systematic acarological studies. For instance, DNA barcoding has been applied to extend the standard descriptions of new mite species (Badek et al. 2008, Dabert et al. 2008, Skoracka 2009, Glowska et al. 2012a, b) and as a tool, which supports phenotypic approach and validates the species status within populations of mites from different hosts, e.g. in Otodectes cynotis (Lohse et al. 2002) or from various niches, e.g. Hygrobates spp. from different types of water habitats (Martin et al. 2010).

In some groups of mites, it is possible to confirm the validity of species status and genetic separation by experimental proof of reproductive barriers using laboratory cross-breeding (Skoracka 2008), but in other groups, such as obligate permanent bird parasites living inside the feather quills and showing low prevalence (syringophilids), this kind of inference is impossible.

Quill mites (Syringophilidae) are currently a subject of intensive taxonomic studies. However, this family is one of the most neglected groups of mites in terms of existing data concerning the biology and ecology of individual species. Within syringophilids, only one species, Syringophiloidus minor (Berlese, 1887), was studied for these aspects (Kethley 1970, 1971, Casto 1974a-c, 1975a-c, 1976) and since then no data have been published.

Despite the fact that host specificity in this group is still the matter of discussion and is largely unresolved, it is believed that both mono- and stenoxenous species are among quill mites. However, identifications of all taxa carried out until recently have been based exclusively on morphological characters. The taxonomic work on this group is regularly biased by difficulties in species identification due to uniform body structure and doubtful differential morphological characters at low taxonomic levels. Therefore, DNA-based identification procedure seems to be a promising approach to resolve the taxonomic 'puzzle' within syringophilids.

In this work we have applied the barcode markers, mitochondrial COI gene fragment and nuclear D2 region of $28 \mathrm{~S}$ rDNA, to test the host specificity and genetic differences of two phenotypically distinct species, namely the stenoxenous Torotrogla merulae Skoracki, Dabert et Ehrnsberger, 2000 parasitizing four turdid bird species (Eurasian blackbird Turdus merula Linnaeus, song thrush Turdus philomelos Brehm, ring ouzel Turdus torquatus Linnaeus and mistle thrush Turdus viscivorus Linnaeus) and the monoxenous Torotrogla rubeculi Skoracki, 2004 recorded exclusively from the European robin Erithacus rubecula (Linnaeus) (Muscicapidae). We show that differences in morphology do not have genetic basis and we hypothesize that they represent evidence of diet-related plasticity, linked to adaptation to local habitat conditions (quill wall thickness adaptation).

\section{MATERIALS AND METHODS}

\section{Animal material}

The material of quill mites used in the study (Table 1) was collected from Eurasian blackbird Turdus merula, song thrush Turdus philomelos and European robin Erithacus rubecula. Torotrogla gaudi Bochkov et Mironov, 1998 from the chaffinch Fringilla coelebs Linnaeus was used as an outgroup for the tree rooting. We did not include in the analysis the material from remaining two hosts of $T$. merulae, the ring ouzel Turdus torquatus and the mistle thrush Turdus viscivorus, because it was unavailable for us. The collection of the material was carried out by E. Glowska in Kopan, Poland (54²7'30"N, 16²5'57"E) during spring migration of birds (monitored by Bird Migration Research Station, University of Gdansk) in April 2009. One feather (among secondaries \#2) was completely removed from each bird specimen, then dissected under the stereomicroscope an Olympus ZS30 and individual mites were removed. Subsequently, transverse sections from the middle part of the quills were made for testing the differences in quill wall thickness between different-sized hosts.

Mites were preserved in 96\% ethyl alcohol and, before mounting on microscopic slides, were subjected to DNA extraction. Vouchers were mounted on slides in Faure medium. Photos and measurements were done by Olympus DP70 digital camera and Olympus BX51 light microscope with Nomarski differential interference contrast (DIC). All measurements are given in micrometres. The exoskeleton of specimens and corresponding DNA samples are deposited in the collection of the Department of Animal Morphology, Faculty of Biology, Adam Mickiewicz University in Poznan, Poland. All sequences have been deposited in GenBank under Accession Nos. as indicated in Table 1.

\section{Molecular analysis}

Total genomic DNA was extracted from the whole specimens using DNeasy Blood \& Tissue Kit (Qiagen GmbH, Hilden, Germany) as described by Dabert et al. (2008). We used sequence data from the cytochrome oxidase subunit I (COI) gene fragment from the mitochondrial genome and D2 region of $28 \mathrm{~S}$ rDNA as a representative of the nuclear DNA.

The cytochrome oxidase subunit I (COI) gene fragment (covering $c a$. $670 \mathrm{bp}$ of the 5'-terminus of COI gene) was amplified by PCR with degenerated primers: bcdF01 (5'-CATTTTCHACTAAYCATAARGATATTGG-3') and bcdR04 (5'-TATAAACYTCDGGATGNCCAAAAAA-3') (Dabert et al. 2010). PCR amplifications were carried out in $10 \mu \mathrm{l}$ reaction volumes containing $5 \mu$ l of Type-it Microsatellite Kit (Qiagen), $0.5 \mu l$ of each primer $(10 \mu \mathrm{M})$, and $4 \mu \mathrm{l}$ of DNA template using a thermocycling profile of one cycle of $5 \mathrm{~min}$ at $95^{\circ} \mathrm{C}$ followed by 35 steps of $30 \mathrm{~s}$ at $95^{\circ} \mathrm{C}, 1 \mathrm{~min}$ at $50^{\circ} \mathrm{C}, 1 \mathrm{~min}$ at $72^{\circ} \mathrm{C}$, with a final step of $5 \mathrm{~min}$ at $72^{\circ} \mathrm{C}$. The amplicons were sequenced in one direction using the primer bedF01 as described below.

Amplification of D2 fragments was done with primers 28F0001 (5'-ACCCVCYNAATTTAAGCATAT-3') and 28R0990 (5'-CCTTGGTCCGTGTTTCAAGAC-3') (Mironov et al. 2012). PCR amplifications were carried out as described above using $0.25 \mu \mathrm{M}$ of each primer. The D2 region was sequenced in both directions using the primer 28R0990 and the internal primer D1D2fw2 (Sonnenberg et al. 2007). After amplification, PCR product was two-fold diluted with water and $5 \mu$ l of the sample was analyzed by electrophoresis on a $1.0 \%$ agarose gel. Samples 
containing visible bands were directly sequenced using $1 \mu 1$ of the PCR reaction and $50 \mathrm{pmol}$ of the relevant sequencing primer. Sequencing was performed with BigDye Terminator v3.1 on an ABI Prism 3130XL Analyzer (Applied Biosystems, Foster City, CA, USA). Sequence chromatograms were checked for accuracy and edited using FinchTV 1.3.1 (Geospiza, Inc., Seattle, WA, USA).

Alignments of the sequence data were prepared manually with GenDoc v.2.7.000 (Nicholas and Nicholas 1997). Pairwise distances between nucleotide COI sequences were calculated using Kimura's 2-parameter (K2P) distance model (Kimura 1980) for all codon positions with MEGA 5.05 software (Tamura et al. 2007). For D2 sequences F81 one-parameter (f81) distance model was applied.

\section{Phylogenetic analysis}

The phylogenetic trees were reconstructed using COI sequences by neighbor-joining (NJ), maximum parsimony (MP), and partitioned maximum likelihood (ML) analyses in MEGA, PAUP*4 (Swofford 2002) and Garli v.2.0 (Zwickl 2006) programs, respectively. The appropriate nucleotide substitution model for each codon position $(1 \mathrm{st}=\mathrm{F} 81,2 \mathrm{nd}=\mathrm{TPM} 2 \mathrm{uf}+\mathrm{I}$, 3rd $=\operatorname{TrN}+\mathrm{G}$ ) was estimated by jModelTest v.0.1.1 (Posada 2008). Support for the recovered trees was evaluated with nonparametric $1000(\mathrm{NJ})$ or 500 (MP, ML) bootstrap replicates (Felsenstein 1985). COI haplotype genealogy was revealed by two methodological approaches: the median-joining (M-J) network approach (Bandelt et al. 1999) as implemented in Network 4.5.1.0p software (http://www.fluxus-technology.com) and the statistical parsimony analysis (SP) using the program TCS v.1.21 (Clement et al. 2000). The M-J procedure was followed by MP-postprocessing (Polzin and Daneschmand 2003) to delete the superfluous links and median vectors in the calculated network. The statistical parsimony (SP) network was calculated to the algorithm of Templeton et al. (1992) with the connection limit set to $95 \%$ that is assumed to be a species threshold (Hart and Sunday 2007). Tree and network visualizations were prepared by tree editing tools in MEGA5 software and Corel Draw X5 graphical software.

\section{RESULTS}

Torotrogla merulae and T. rubeculi (Fig. 1A, B) are morphologically easily distinguishable and well defined by the following characters: (1) size and shape of hypostomal median protuberances (7-12.5 $\mu \mathrm{m}$ long, thin and sharp-ended in females of T. merulae and 4.1-7.0 $\mu \mathrm{m}$ long, wide and blunt-ended in females of $T$. rubeculi; Figs. 1C, D, 2A), (2) length of distal movable digit of chelicerae (digitus mobilis) (150-190 $\mu \mathrm{m}$ long in T. merulae and 135-140 $\mu \mathrm{m}$ in T. rubeculi, respectively; Figs. 1C, D, 2B), (3) length of stylophore (215-245 $\mu \mathrm{m}$ and $185-195 \mu \mathrm{m}$ in T. merulae and T. rubeculi, respectively; Figs. 1C, D, 2C), (4) arrangement of propodonotal setae $c 2$ and se (in T. merulae situated at the same transversal level and in $T$. rubeculi $c 2$ situated anterior to se; Fig. 1E, F).

Even though the dissimilarities in morphology are well expressed and not overlapping (Fig. 2), they are not supported by the genetic distances between nucleotide se- quences, the topology of the reconstructed phylogenetic trees and haplotype genealogy.

The COI alignment we used in the study comprised 48 sequences of ingroup and four of outgroup (with $528 \mathrm{bp}$ each), which arranged in thirteen and three haplotypes, respectively. In contrast, the D2 alignment included 17 sequences of ingroup and three of outgroup

Table 1. Animal material (specimens) used in this study.

\begin{tabular}{|c|c|c|c|c|c|}
\hline \multirow{2}{*}{$\begin{array}{l}\text { Torotrogla } \\
\text { species }\end{array}$} & \multicolumn{2}{|c|}{ Host } & \multirow{2}{*}{$\begin{array}{c}\text { Voucher code } \\
\text { (specimen }+ \\
\text { DNA) }\end{array}$} & \multicolumn{2}{|c|}{ GenBank Access No. } \\
\hline & species & $\begin{array}{l}\text { indivi- } \\
\text { dual ID }\end{array}$ & & $\mathrm{COI}$ & D2 \\
\hline \multirow{30}{*}{$\begin{array}{c}\text { Torotrogla } \\
\text { merulae }\end{array}$} & \multirow{17}{*}{$\begin{array}{l}\text { Turdus } \\
\text { merula }\end{array}$} & \multirow[t]{10}{*}{$\# 1$} & TME001 & JN160640 & JQ349418 \\
\hline & & & TME002 & JN160632 & JQ349411 \\
\hline & & & TME034 & JN160633 & - \\
\hline & & & TME035 & JN160634 & - \\
\hline & & & TME036 & JF808654 & JQ349419 \\
\hline & & & TME088 & JF808657 & JQ349415 \\
\hline & & & TME089 & JF808658 & - \\
\hline & & & TME090 & JF808659 & JQ349412 \\
\hline & & & TME092 & JN160639 & JQ349413 \\
\hline & & & TME093 & JN160635 & JN896628 \\
\hline & & \multirow[t]{4}{*}{$\# 2$} & TME094 & JN160609 & - \\
\hline & & & TME096 & JN160610 & - \\
\hline & & & TME097 & JN160611 & - \\
\hline & & & TME098 & JF808660 & - \\
\hline & & \multirow[t]{3}{*}{$\# 3$} & TME099 & JN160612 & JQ349414 \\
\hline & & & TME101 & JN160613 & - \\
\hline & & & TME102 & JN160614 & - \\
\hline & \multirow{13}{*}{$\begin{array}{c}\text { Turdus } \\
\text { philomelos }\end{array}$} & \multirow[t]{8}{*}{$\# 1$} & TME004 & JF808652 & - \\
\hline & & & TME005 & JF808653 & - \\
\hline & & & TME037 & JF808655 & JQ349417 \\
\hline & & & TME038 & JF808656 & - \\
\hline & & & TME039 & JN160636 & - \\
\hline & & & TME104 & JN160637 & - \\
\hline & & & TME107 & JN160638 & - \\
\hline & & & TME108 & JF808661 & - \\
\hline & & \multirow[t]{5}{*}{$\# 2$} & TME109 & JF808662 & - \\
\hline & & & TME110 & JF808663 & - \\
\hline & & & TME111 & JN160615 & JQ349416 \\
\hline & & & TME112 & JN160616 & - \\
\hline & & & TME113 & JQ302303 & - \\
\hline \multirow{18}{*}{$\begin{array}{c}\text { Torotrogla } \\
\text { rubeculi }\end{array}$} & \multirow{18}{*}{$\begin{array}{l}\text { Erithacus } \\
\text { rubecula }\end{array}$} & \multirow[t]{9}{*}{$\# 1$} & TRU028 & JN160617 & - \\
\hline & & & TRU029 & JN160618 & JQ349405 \\
\hline & & & TRU052 & JN160619 & - \\
\hline & & & TRU053 & JN160620 & - \\
\hline & & & TRU054 & JN160621 & JQ349407 \\
\hline & & & TRU164 & JN160622 & - \\
\hline & & & TRU165 & JN160623 & - \\
\hline & & & TRU166 & JN160624 & - \\
\hline & & & TRU167 & JN160625 & - \\
\hline & & \multirow[t]{7}{*}{$\# 2$} & TRU169 & JF808664 & JQ349408 \\
\hline & & & TRU170 & JN160626 & - \\
\hline & & & TRU171 & JN160627 & JN896627 \\
\hline & & & TRU172 & JN160628 & - \\
\hline & & & TRU173 & JN160629 & JQ349409 \\
\hline & & & TRU174 & JN160630 & JQ349410 \\
\hline & & & TRU175 & JN160631 & JQ349406 \\
\hline & & \multirow[t]{2}{*}{$\# 3$} & TRU195 & JQ302305 & - \\
\hline & & & TRU197 & JQ302304 & - \\
\hline \multirow{4}{*}{$\begin{array}{l}\text { Torotrogla } \\
\quad \text { gaudi }\end{array}$} & \multirow{4}{*}{$\begin{array}{c}\text { Fringilla } \\
\text { coelebs }\end{array}$} & $\# 1$ & TGA032 & JF808649 & JQ349403 \\
\hline & & & TGA046 & JQ302306 & - \\
\hline & & $\# 2$ & TGA179 & JF808650 & JQ349404 \\
\hline & & & TGA182 & JF808651 & JN896626 \\
\hline
\end{tabular}



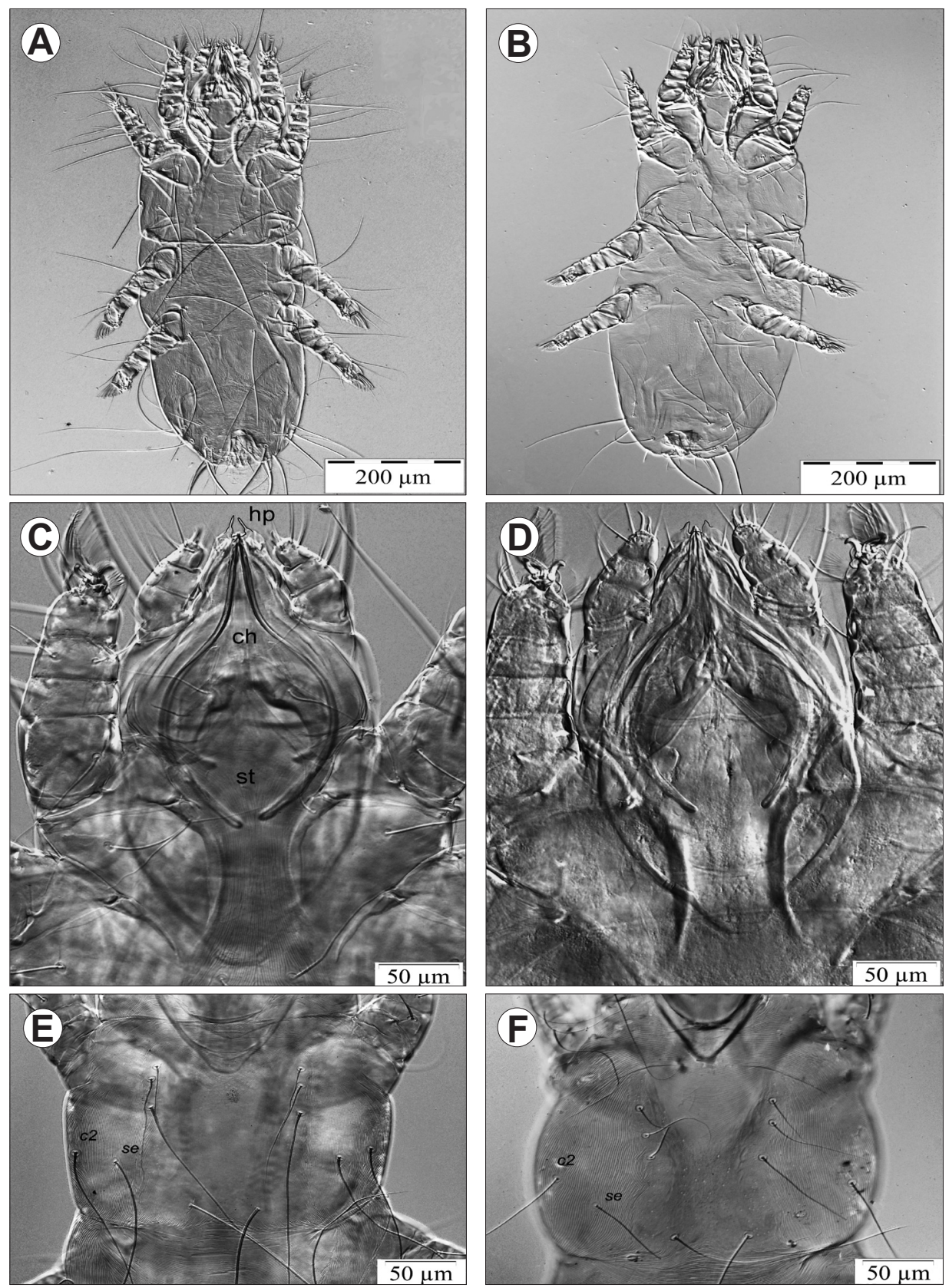

Fig. 1. Morphological characters of Torotrogla merulae and T. rubeculi (females). A-general view of T. merulae; B - general view of T. rubeculi; $\mathbf{C}$ - gnathosoma of T. merulae; $\mathbf{D}$ - gnathosoma of T. rubeculi; $\mathbf{E}$ - propodonotum of T. merulae; $\mathbf{F}$ - propodonotum of T. rubeculi. Abbreviations: $c 2$ - propodonotal seta; $\mathrm{ch}$ - chelicerae; hp - hypostomal protuberances; se - propodonotal seta; st - stylophore.

(with $755 \mathrm{bp}$ each) arranged in two and one haplotypes, respectively.

Thirteen COI sequences of T. merulae occurring on the song thrush varied in 23 sites and could be arranged into seven different haplotypes. Among polymorphic sites, four non-synonymous changes were observed leading to the following amino acid substitutions: Leu7Ser, Ile77Thr, Met96Val and Gly97Ser. Three first substitutions occurred among $T$. merulae sequences, the fourth one between $T$. gaudi and ingroup sequences. Seventeen
COI sequences of $T$. merulae occurring on the blackbird varied in ten sites and could be arranged into five different haplotypes. Among polymorphic sites, two non-synonymous changes were observed in sites 7 and 77 as in case mentioned above. Eighteen sequences of T. rubeculi specimens varied in five sites and revealed two haplotypes with no non-synonymous changes observed.

The distances among COI haplotypes within analyzed Torotrogla species were relatively low and averaged from $0.1 \%$ to $0.8 \%$; only in population of $T$. merulae occurring 
Table 2. Estimates of evolutionary divergence (in \%) between COI (below diagonal) and D2 (above diagonal) sequences of investigated Torotrogla species.

\begin{tabular}{|c|c|c|c|c|c|c|}
\hline \multirow{3}{*}{ Species } & \multicolumn{6}{|c|}{ Distances } \\
\hline & \multicolumn{2}{|c|}{ Within groups } & \multicolumn{4}{|c|}{ Between groups } \\
\hline & $\mathrm{COI}$ & D2 & 1. & 2. & 3. & 4. \\
\hline 1. T. gaudi & 0.8 & 0.1 & & 4.4 & 4.4 & 4.3 \\
\hline 2. T. merulae from T. philomelos & 2.0 & 0.0 & 10.4 & & 0.0 & 0.1 \\
\hline 3. T. merulae from T. merula & 0.6 & 0.0 & 10.9 & 1.8 & & 0.1 \\
\hline 4. T. rubeculi & 0.1 & 0.0 & 10.9 & 2.4 & 1.6 & \\
\hline
\end{tabular}

on the song thrush the level of differentiation was relatively high and amounted $2.0 \%$ (Table 2). The intraspecific divergence in D2 sequences (20 sequences analyzed revealed one haplotype for each species) averaged from $0 \%$ to $0.1 \%$.

The distances between COI sequences of T. merulae and $T$. rubeculi were low (1.6-2.4\%), whereas between ingroup and outgroup amounted 10.4-10.9\% (Table 2). The distances between D2 region sequences of T. merulae and T. rubeculi were also low at the intraspecific level $(0.1 \%)$; in fact these two species differ in this gene fragment by only one G/A transition. The distances between T. gaudi and T. merulae and T. rubeculi were $4.4 \%$ and $4.3 \%$, respectively (Table 2 ).

The topologies of the reconstructed phylogenetic trees also do not support the species status of T. rubeculi (Fig. 3). All three analyses (NJ, MP, ML) placed T. rubeculi as a well-supported clade but nested it within $T$. merulae clade. Individuals of $T$. merulae collected from the blackbird and the song thrush mostly do not group in separate clades but are mixed up in various parts of the trees. In spite of the fact that the basal clades are poorly resolved in most trees, the basal branches of all trees are occupied by haplotypes of $T$. merulae originating from the song thrush.

The revealed haplotype genealogy supports the conspecific status of T. merulae and T. rubeculi (Fig. 4). Haplotypes of T. rubeculi originated within the haplotypes of T. merulae, probably coming from the populations inhabiting the blackbird. The M-J network (Fig. 4A) shows two distinct haplotype lines: the first line belonging purely to T. merulae from the song thrush, the second one containing haplotypes from all three host species, including T. rubeculi from the robin. In this second line, there is evident gene flow between mite populations from the blackbird and song thrush. The population from the robin is very homogeneous and no evidence of reverse gene flow (after the primary switch from the blackbird) is observed. The SP approach (Fig. 4B) reveals a similar situation. The $95 \%$ connection limit divides the graph into three separate subnetworks: the first one grouping haplotypes of the outgroup T. gaudi, the second one corresponding to the first line of M-J network containing exclusively hap-
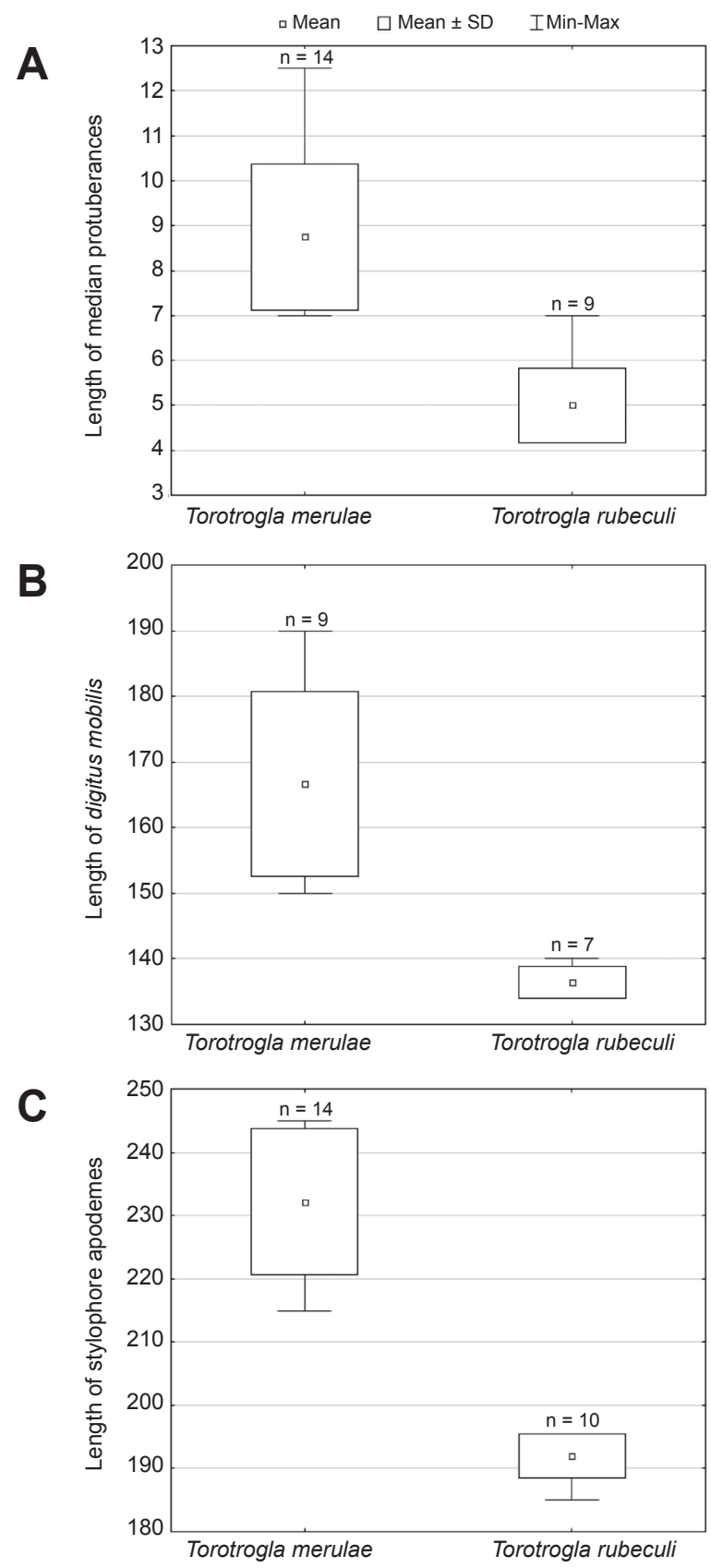

Fig. 2. Differences in the length (with mean, SD, min.-max.) of median protuberances (A), distal movable digit of chelicerae (digitus mobilis) (B) and stylophore apodemes (C) in females of Torotrogla merulae and T. rubeculi, respectively.

lotypes from the song thrush, and the third one connecting all remaining haplotypes of $T$. merulae from the blackbird and song thrush, and T. rubeculi from the robin.

\section{DISCUSSION}

In our analysis, we showed the incompatibilities between morphological and molecular delimitations of species boundaries in syringophilid mites. Since detected differences between Torotrogla merulae and T. rubeculi 


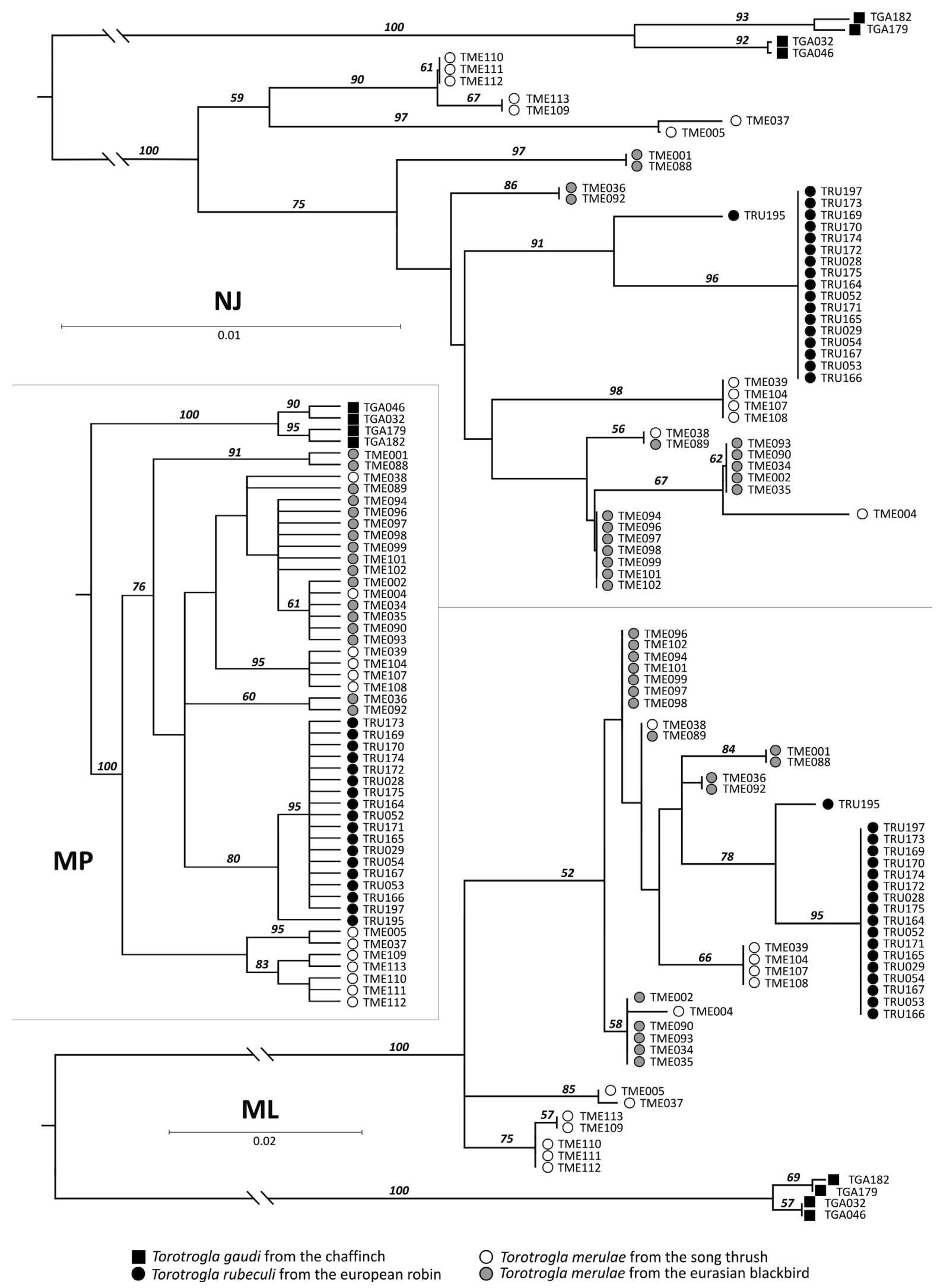

Fig. 3. NJ, MP, and ML phylogenetic trees of COI sequences of Torotrogla merulae and T. rubeculi. Black squares - haplotypes of T. gaudi (outgroup); white circles - haplotypes of T. merulae from Turdus philomelos; black circles - haplotypes of T. rubeculi; gray circles - haplotypes of T. merulae from Turdus merula; the numbers on branches show the bootstrap support. 


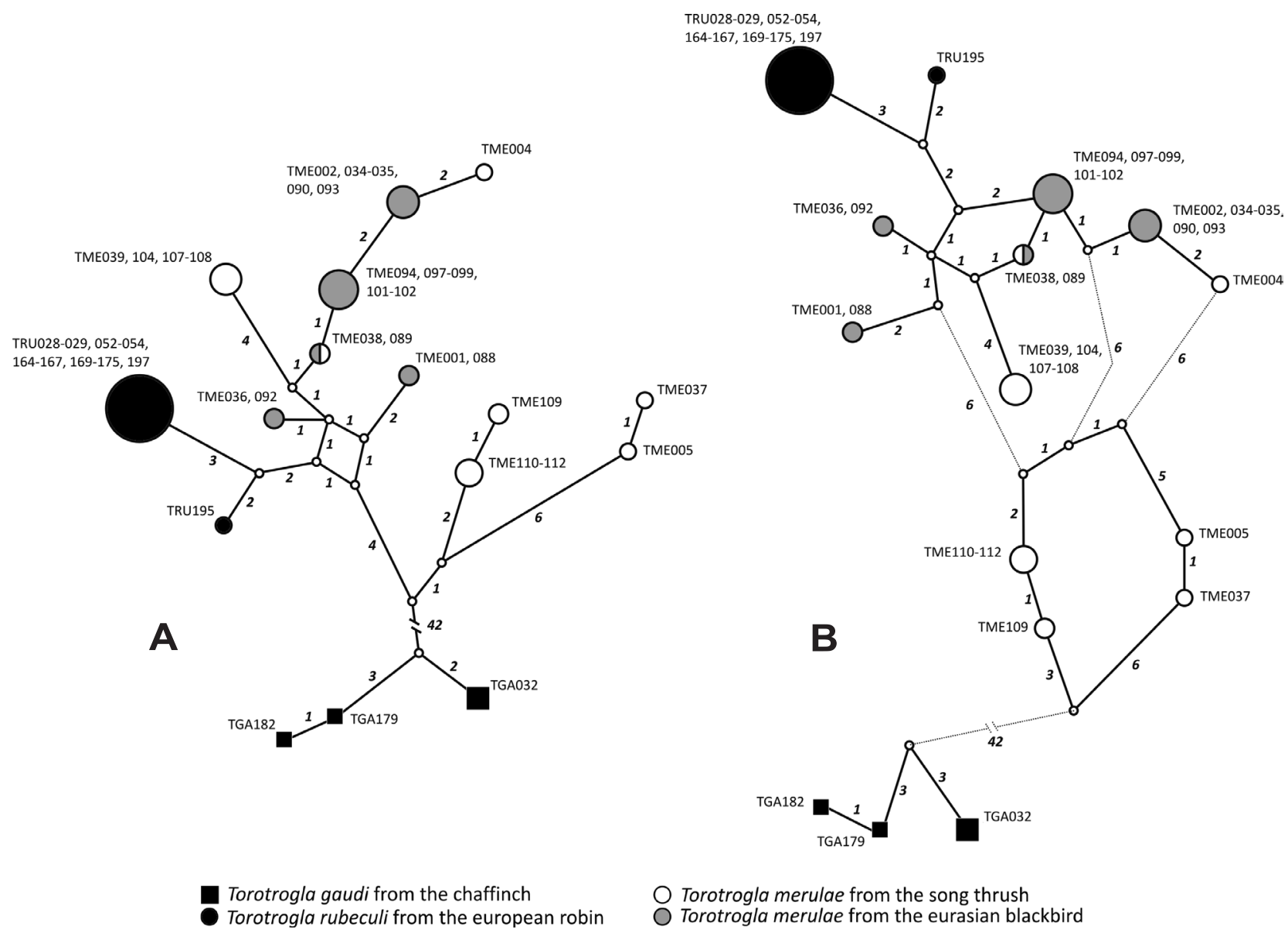

Fig. 4. Median-joining (A) and statistical parsimony (B) networks showing the genealogical relationships between analyzed haplotypes. The size of a figure is proportional to the haplotype frequency. Small hollow circles represent missing (hypothetical) intermediate haplotypes. The numbers above branches indicate the number of mutational steps between haplotypes. The figures and colours describe the haplotypes as in Fig. 3. Dotted lines in statistical parsimony networks show the mutational connection at the lowered probability of parsimony from $95 \%$ to $94 \%$.

populations (1.6-2.4\% for COI and $0.1 \%$ for $\mathrm{D} 2)$ are comparable to the intraspecific level $(0.0-2.1 \%$ for COI, $0.0-0.1 \%$ for D2) observed in majority of currently recognized European Torotrogla species and are much lower than the interspecific distances $(9.6-14.7 \%$ for COI and $4.3-4.4 \%$ for D2) observed in the genus (Glowska, unpublished data), and the phylogenetic and genealogical structure do not support their separation, we postulate their conspecificity.

According to the network analysis results, the populations living on the robin originated from mites inhabiting the blackbird. Insignificant intrapopulation differences between haplotypes inhabiting E. rubecula point most likely on a recent origin of this, perhaps accidental, host shift. Although the haplotypes of T. rubeculi are nested now within $T$. merulae, the restriction on gene flow between morphs is observed. Despite the present conspecific character of these populations, it is very likely that divergent habitat preferences will reflect in the future accumulated genetic variation due to disruption of gene flow between populations, which could lead to genetic divergence and, subsequently, speciation into separate species. This is even more probable because of the vertical scheme of quill mites dispersion and strong isolation of occupied niches.

It is worthy to mention that the statistical parsimony (SP) network analysis recognizes two separate, disconnected haplotype subnetworks in the Torotrogla merulaerubeculi complex, one limited exclusively to haplotypes found on the song thrushes and the second one grouping remaining haplotypes from all three host species. According to recent investigations, it is suggested that such separate SP subnetworks correspond to Linnean species (Hart and Sunday 2007, Chen et al. 2010). However, at the present state of knowledge, we do not incline to conclude that these two subnetworks should be considered as separate species. Lowering the probability of parsimony from $95 \%$ to $94 \%$ in SP analysis produces one network of T. merulae and T. rubeculi haplotypes (Fig. 4B, dotted lines). To draw any systematic conclusion on this issue 

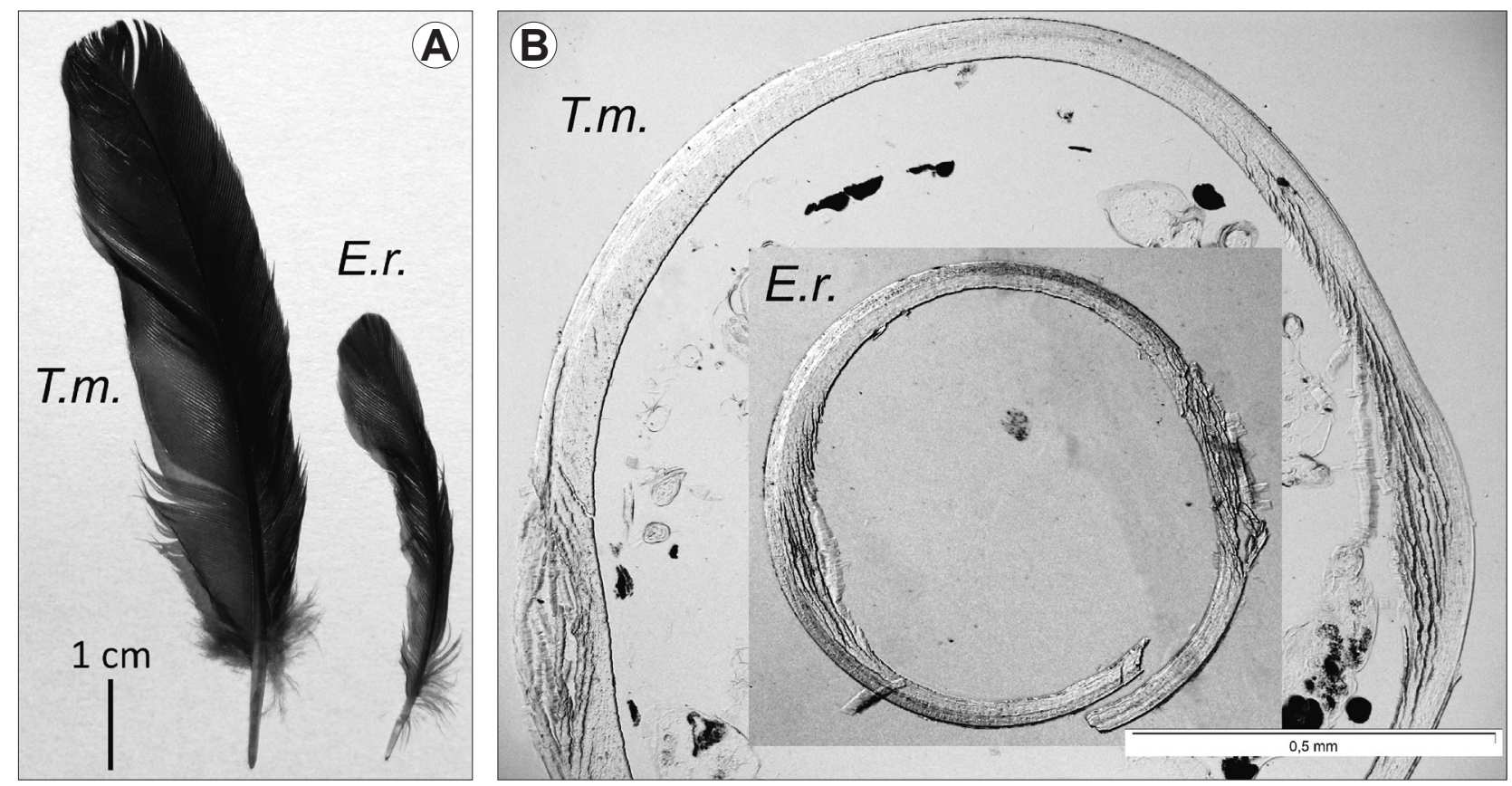

Fig. 5. Differences in dimensions of the flight feathers (secondaries No. 2) (A) and quill wall thickness (B) between Eurasian blackbird Turdus merula and European robin Erithacus rubecula being hosts of Torotrogla merulae and T. rubeculi, respectively; T.m. - Turdus merula, E.r. - Erithacus rubecula.

we would need much more extensive haplotype sampling from all host species and from more numerous host individuals.

The phenotype is a product of the interaction of inherited genetic information with the environment, so the further question we pose is: if we are dealing just with a single species, what is the reason of such morphological distinctions? Actually, we do not know the real cause of the presence of two morphotypes. The character of differences between $T$. merulae and T. rubeculi (mainly structures used for feeding) leads us to assume that it should be linked with diet-related plasticity.

In the context of phenotypic plasticity (the ability of a single genotype to produce multiple phenotypes in response to environmental changes) and its role in the evolutionary processes, syringophilids seem to be very interesting object for consideration because of some reasons: specific habitat occupied (quill), strategy of gaining food (piercing quill's wall using chelicerae and feeding surrounding soft tissue), way of dispersion (mainly vertical transfer) (Kethley 1970, Skoracki et al. 2010) and presumed evolutionary mode (resource tracking - following the optimum parameters of quills' volume and adjustment most favourable correlation between length of digitus mobilis and wall thickness) (Kethley and Johnston 1975).

The thrush is a bird larger in size than the European robin and has larger secondaries (Fig. 5A) with thicker quill wall (Fig. 5B). The diversifying characteristics are most probably related to different thickness of quill wall (in blackbird 58-81 $\mu \mathrm{m}$, mean $66 \pm 10 \mu \mathrm{m}$; in robin $35-$
$46 \mu \mathrm{m}$, mean $38 \pm 4 \mu \mathrm{m})$. Torotrogla merulae occupies the secondaries of the thrush and needs longer chelicerae to pierce the quill than $T$. rubeculi inhabiting thin-walled quills. Sharp-ended tip of hypostomal protuberances in T. merulae may also additionally fix the hypostom in quill wall during food uptake. This is the reason why we connected these morphological differences with diet-related specialization, which is adaptation facilitating resource exploitation after colonization of new environment (likely recent transfer from blackbird to robin).

Such response involving adjustment of organism at the level of the nutrition-dependent expression is common and was recorded in many taxa. For example, differences in pharyngeal jaw expression between the Midas cichlid fish groups were attributable to the diet's mechanical resistance (Muschick et al. 2011) and alternative morphologies in the mouth of the nematode Pristionchus pacificus Sommer, Carta, Kim et Sternberg, 1996 and formation of teeth-like structures associated with feeding (Kiontke and Fitch 2010).

In some cases such ecological divergence can initiate speciation if subsets of a species or population evolve to specialize to different ecological resources and the resulting phenotypic modes become reproductively isolated. It opens up opportunities for diversification including speciation, e.g. the features of large and small beak morphs in medium ground finch, which diverged in response to variation in local food availability (Huber et al. 2007). In this case, it was demonstrated that two morphs showed strong positive assortative pairing and restriction of gene flow 
between them was observed, which strongly supports the central role of ecological factor in the early stages of adaptive radiation.

On the example of Torotrogla merulae and T. rubeculi we showed that different taxonomic characters such as morphology and DNA sequence data do not always diversify in a coordinated way. Basing on DNA-barcoding results presented in this paper we opt for acknowledging the conspecificity of these species and explaining the morphological differences as a result of phenotypic plasticity. We also admit that DNA sequences are not the only depositories of evolutionary history and they should be complemented by additional data, including breeding, ecology, and other crucial features, which potentially would give its own contribution to the species specificity. That is the reason why we refuse to draw any formal systematic move (as species synonymization), which would need not only much more extensive haplotypes sampling from all host species and from more numerous host individuals, but also a wide comprehensive knowledge on all fields mentioned above, which, in the case of quill mites, is still far from satisfactory.

Acknowledgements. We would thank to Dr. M. Dabert, Molecular Techniques Laboratory, A. Mickiewicz University, Poznan, for valuable comments on the manuscript. We also would like to express our gratitude to Dr. H. Proctor, Department of Biological Sciences, University of Alberta, Edmonton, Canada for important comments on the first version of the manuscript, to Dr. J. K. Nowakowski, Bird Migration Research Station, University of Gdansk for the permission to collect the material and Dr. E. Gabała, Department of Cell Biology, A. Mickiewicz University, for help with the preparation of quill sections. This study was supported by the Ministry of Science and Higher Education (grant no. N N303 561 939).

\section{REFERENCES}

Badek A., Dabert M., Mironov S.V., Dabert J. 2008: New species of the genus Proctophyllodes (Analgoidea, Proctophyllodidae) from the cetti's warbler Cettia cetti (Passeriformes; Sylviidae) with DNA barcode data. Ann. Zool. 58: 397-402.

Bandelt H.J., Forster P., RöHl A. 1999: Median-joining networks for inferring intraspecific phylogenies. Mol. Biol. Evol. 16: $37-48$.

CAsto S.D. 1974a: Quill wall thickness and feeding of Syringophiloidus minor (Berlese) (Acarina: Syringophilidae). Ann. Entomol. Soc. Am. 67: 824.

CAsto S.D. 1974b: Entry and exit of syringophilid mites (Acarina: Syringophilidae) from the lumen of the quill. Wilson Bull. 86: 272-278.

CASTO S.D. 1974c: A nocturnal dispersal rhythm in the quill mite, Syringophiloidus minor (Berlese) (Prostigmata: Syringophilidae). J. Med. Entomol. 11: 113-114.

Casto S.D. 1975a: Generation time of male quill mites Syringophiloidus minor (Berlese) (Acarina: Syringophilidae). Am. Midl. Nat. 93: 495-498.

CAsto S.D. 1975b: The effect of the postjuvenal molt in the house sparrow on infestations of the quill mite, Syringophiloidus minor (Berlese) (Acarina: Syringophilidae). J. Med. Entomol. 12: 23-27.

CAsto S.D. 1975c: Mortality in the quill mite, Syringophiloidus minor (Acarina: Syringophilidae). Ann. Entomol. Soc. Am. 68: 551-552.

CAsto S.D. 1976: Host records and observations of quill mites (Acarina: Syringophilidae) from Texas birds. Southwest. Entomol. 1: 155-160.

Chen H., Strand M., Norenburg J.L., Shichun S., Kajihara H., Chernyshev A.V., Maslakova S.A., Sundberg P. 2010: Statistical parsimony networks and species assemblages in cephalotrichid nemerteans (Nemertea). PLoS One 5: e12885.

Clement M., Posada D., Crandall K.A. 2000: TCS: a computer program to estimate gene genealogies. Mol. Ecol. 9: 1657-1660.

DABert J., Ehrnsberger R., DABert M. 2008: Glaucalges tytonis sp. n. (Analgoidea, Xolalgidae) from the barn owl Tyto alba (Strigiformes, Tytonidae): compiling morphology with DNA barcode data for taxon descriptions in mites (Acari). Zootaxa 1719: 41-52.
Dabert M., Witalinski W., Kazmierski A., Olszanowski Z., DABERT J. 2010: Molecular phylogeny of acariform mites (Acari, Arachnida): strong conflict between phylogenetic signal and long-branch attraction artifacts. Mol. Phylogenet. Evol. 56: $222-241$.

Felsenstein J. 1985: Confidence limits on phylogenies: an approach using the bootstrap. Evolution 39: 783-791.

Glowska E., Dragun-Damian A., Dabert J. 2012a: Picobia dziabaszewskii sp. nov. (Acari, Syringophilidae) - combined description (morphology with DNA barcode data) of a new quill mite species parasitizing Garrulax formosus (Passeriformes: Leiothrichidae). Zootaxa 3224: 57-61.

Glowska E., Dragun-Damian A., Dabert J. 2012b: A new quill mite Syringophiloidus pseudonigritae sp. nov. (Prostigmata, Syringophilidae) parasitizing Pseudonigrita arnaudi (Passeriformes, Ploceidae) - a combined description using morphology and DNA barcode data. Zootaxa 3532: 64-68.

Harper J.T., Gile G.H., James E.R., Carpenter K.J., Keeling P.J. 2009: The inadequacy of morphology for species and genus delineation in microbial eukaryotes: an example from the parabasalian termite symbiont Coronympha. PLoS ONE 4: e677.

Hart M.W., Sunday J. 2007: Things fall apart: biological species form unconnected parsimony networks. Biol. Lett. 3: 509-512.

Hebert P.D.N., Penton E.H., Burns J.M., Janzen D.H., HallWACHS W. 2004: Ten species in one: DNA barcoding reveals cryptic species in the neotropical skipper butterfly Astraptes fulgerator. Proc. Natl. Acad. Sci. USA 101: 14812-14817.

Hebert P.D.N., Ratnasingham S., De Waard J.R. 2003: Barcoding animal life: cytochrome $\mathrm{c}$ oxidase subunit I divergences among closely related species. Proc. R. Soc. Lond. B, Biol. Sci. 270 (Suppl.): 96-99.

Huber S.K., De León L.F., Hendry A.P., Bermingham E., Podos J. 2007: Reproductive isolation of sympatric morphs in a population of Darwin's finches. Proc. Biol. Sci. 274: 1709-1714.

Johnson S.B., Warén A., VRiJenhoek R.C. 2008: DNA barcoding of Lepetodrilus limpets reveals cryptic species. J. Shellfish Res. 27: 43-51.

Kethley J.B. 1970: A revision of the family Syringophilidae (Prostigmata: Acarina). Contrib. Am. Entomol. Inst. 6: 1-76. 
Kethley J.B. 1971: Population regulation in quill mites (Acari: Syringophilidae). Ecology 52: 1113-1118.

Kethley J.B., Johnston D.E. 1975: Resource tracking patterns in bird and mammal ectoparasites. Misc. Publ. Entomol. Soc. Am. 9: 227-236.

Kimura M. 1980: A simple method for estimating evolutionary rate of base substitutions through comparative studies of nucleotide sequences. J. Mol. Evol. 16: 111-120.

Kiontke K., Fitch D.H.A. 2010: Phenotypic plasticity: different teeth for different feasts. Curr. Biol. 20: R710-R712.

Lohse J., Rinder H., Gothe R., Zahler M. 2002: Validity of species status of the parasitic mite Otodectes cynotis. Med. Vet. Entomol. 16: 133-138.

Lumley L.M., SperLing A.H. 2010: Integrating morphology and mitochondrial DNA for species delimitation within the spruce budworm (Choristoneura fumiferana) cryptic species complex (Lepidoptera: Tortricidae). Syst. Entomol. 35: 416-428.

Martin P., Dabert M., Dabert J. 2010: Molecular evidence for species separation in the water mite Hygrobates nigromaculatus Lebert, 1879 (Acari, Hydrachnidia): evolutionary consequences of the loss of larval parasitism. Aquat. Sci. 72: 347-360.

Mironov S.V., Dabert J., Dabert M. 2012: A new feather mite species of the genus Proctophyllodes Robin, 1877 (Astigmata, Proctophyllodidae) from the long-tailed tit Aegithalos caudatus (Passeriformes: Aegithalidae) - morphological description with DNA barcode data. Zootaxa 3253: 54-61.

Muschick M., Barluenga M., Salzburger W., Meyer A. 2011: Adaptive phenotypic plasticity in the Midas cichlid fish pharyngeal jaw and its relevance in adaptive radiation. BMC Evol. Biol. 11: 116

Nicholas K.B., Nicholas H.B. Jr. 1997: GeneDoc: a tool for editing and annotating multiple sequence alignments. Pittsburgh Supercomputing Center's National Resource for Biomedical Supercomputing, ver. 2.7.000. http://www.nrbsc.org/downloads (accessed 2 March 2007).

van Niekerk J.M., Crous P.W., Groenewald J.Z., Fourie P.H., Halleen F. 2004: DNA phylogeny, morphology and pathogenicity of Botryosphaeria species on grapevines. Mycologia 96: 781-798.

Otranto D., Milillo P., Traversa D., Colwell D.D. 2005: Morphological variability and genetic identity in Rhinoestrus spp. causing horse nasal myiasis. Med. Vet. Entomol. 19: 96100.

Otsuka S., Suda S., Li R., Watanabe M., Oyaizu H., Matsumoto S., Watanabe M.M. 1999: Phylogenetic relationships between toxic and non-toxic strains of the genus Microcystis based on $16 \mathrm{~S}$ to $23 \mathrm{~S}$ internal transcribed spacer sequence. FEMS Microbiol. Lett. 172: 15-21.

Pegler K.R., Evans L., Stevens J.R., Wall R. 2005: Morphological and molecular comparison of host-derived populations of parasitic Psoroptes mites. Med. Vet. Entomol. 19: 392-403.

Polzin T., Daneschmand S.V. 2003: On Steiner trees and minimum spanning trees in hypergraphs. Oper. Res. Lett. 31: 12-20.

Posada D. 2008: ModelTest: phylogenetic model averaging. Mol. Biol. Evol. 25: 1253-1256.
SBORDONI V. 2010: Strength and limitations of DNA barcode under the multidimensional species perspective. In: P.L. Nimis and R. V. Lebbe (Eds.), Tools for Identifying Biodiversity: Progress and Problems. Proceedings of the International Congress, Paris, 20-22 September 2010, EUT Edizioni, Università di Trieste, pp. $275-280$.

Skoracka A. 2008: Reproductive barriers between populations of the cereal rust mite Abacarus hystrix confirm their host specialization. Evol. Ecol. 22: 607-616.

Skoracka A. 2009: Description of Abacarus lolii n. sp. (Prostigmata: Eriophyoidea: Eriophyidae), a cryptic species within a grass-feeding Abacarus complex. Int. J. Acarol. 35: 405-417.

Skoracka A., Dabert M. 2010: The cereal rust mite Abacarus hystrix (Acari: Eriophyoidea) is a complex of species: evidence from mitochondrial and nuclear DNA sequences. Bull. Entomol. Res. 100: 263-272.

Skoracki M., Michalik J., Sikora B. 2010: Prevalence and habitat preference of quill mites (Acari, Syringophilidae) parasitizing forest passerine birds in Poland. Acta Parasitol. 55: 188-193.

Sonnenberg R., Nolte A.W., Tautz D. 2007: An evaluation of LSU rDNA D1-D2 sequences for their use in species identification. Front. Zool. 4: 6

Sperling F.A. 2003: DNA Barcoding: Deus ex Machina. Newsletter Biol. Surv. Canada (Terrestrial Arthropods) 22: 50-53.

Swofford D.L. 2002: PAUP*. Phylogenetic analysis using parsimony (*and other methods), version 4.0b10. Sinauer Associates, Sunderland, MA.

Tamura K., Dudley J., Nei M., Kumar S. 2007: MEGA4: Molecular Evolutionary Genetics Analysis (MEGA) software version 4.0. Mol. Biol. Evol. 24: 1596-1599.

Tautz D., Arctander P., Minelli A., Thomas R.H., Vogler A.P. 2003: A plea for DNA taxonomy. Trends Ecol. Evol. 18: $70-74$.

Templeton A.R., Crandall K.A., Sing C.F. 1992: A cladistic analysis of phenotypic associations with haplotypes inferred from restriction endonuclease mapping and DNA sequence data. III. Cladogram estimation. Genetics 132: 619-633.

VRIJENHOEK R.C. 2009: Cryptic species, phenotypic plasticity, and complex life histories: assessing deep-sea faunal diversity with molecular markers. Deep-Sea Res. (2 Top. Stud. Oceanogr.) 56: 1713-1723.

Will K.W., Rubinoff D. 2004: Myth of the molecule: DNA barcodes for species cannot replace morphology for identification and classification. Cladistics 20: 47-55.

Wilson J.J., Landry J.-F., Janzen D.H., Hallwachs W., Nazari V., Hajibabaei M., Hebert P.D.N. 2010: Identity of the ailanthus webworm moth (Lepidoptera, Yponomeutidae), a complex of two species: evidence from DNA barcoding, morphology and ecology. ZooKeys 46: 41-60.

ZwICKL D.J. 2006: Genetic algorithm approaches for the phylogenetic analysis of large biological sequence datasets under the maximum likelihood criterion. Ph.D. dissertation, The University of Texas at Austin, $115 \mathrm{pp}$. 